\title{
Molar-Incisor Hypomineralisation and Allergic March
}

\section{Molarno-incizalna hipomineralizacija i alergijska stanja}

\author{
${ }^{1}$ School of Dentistry. University of Barcelona, Spain. \\ Stomatološki fakultet Sveučilišta u Barceloni, Španjolska \\ 2 Research Suport Unit. University Institute for Research in Primary Care (IDIAP Jordi Gol), Barcelona, Spain. \\ Jedinica za podršku u istraživanju, Sveučilišni institut za istraživanje u primarnoj zaštiti (IDIAP Jordi Gol), Barcelona, Španjolska
}

\section{Abstract}

Background: Molar-incisor hypomineralisation is a disturbance in dental development that involves first permanent molars as well as permanent incisors with a prevalence that ranges from $2.5 \%$ to $40 \%$. Aim: The objective of this study was to investigate the effect of atopic diseases on the development of molar-incisor hypomineralisation. Material and methods: The study was based on the review of the medical records of a group of 102 children whose age was between eight and 12 years and 11 months and who had previously been diagnosed with MIH. Results: An association $\left(x^{2}, p \leq 0.05\right)$ has been found between molar-incisor hypomineralisation in children's mouths and the existence of: atopic dermatitis $(\mathrm{OR}=2.504 ; 1.54-4.05 \mathrm{Cl} 95 \%)$, food allergies $(\mathrm{OR}=2.171 ; 1.03-4.56 \mathrm{Cl} 95 \%)$, allergic rhinitis $(\mathrm{OR}=0.17 ; 0.02-1.27 \mathrm{Cl} 95 \%)$, and asthmatic bronchitis/asthma $(\mathrm{OR}=1.707 ; 1.05-2.76 \mathrm{Cl}$ $95 \%$ ). When analyzing the pathologies by location, we found that atopic dermatitis, food allergies, allergic rhinitis and asthma were more frequent in children who had $(p \leq 0.05) \# 12, \# 11, \# 21, \# 22$, \#36, \#31, \#41 and \#42 affected. Conclusions: The association between molar-incisor hypomineralisation and the presence of atopic diseases in the first 36 months of life underlines the convenience of approaching this problem from a multidisciplinary perspective.
Received: January 1, 2020

Accepted: April 15, 2020

Address for correspondence

Prof. M. Hernández

University of Barcelona

Dental School

Department of Pediatric Dentistry

Feixa Llarga s/n, 08907

L'Hospitalet de Llobregat, Barcelona, Spain.

Tel: +34934024269

Fax: +34934035 558

m_hernandez_j@ub.edu

Key words

Dental Enamel Hypoplasia; Atopic Der-

matitis; Food Hypersensitivity; Allergic

Rhinitis; Tooth Demineralization; Child

\section{Introduction}

The meeting of the European Academy of Paediatric Dentistry (EAPD), held in Athens in 2003, accepted the terminology "molar-incisor hypomineralisation" (MIH), suggested by Weerheijm et al. in 2001, (1). MIH refers to an alteration of the dental development of unknown etiology that affects permanent first molars while permanent incisors may be affected as well (2).

Studies on MIH have been widespread and are currently being studied in almost every country in the world. The prevalence figures that are being considered today vary between $2.4 \%$ and $40.2 \%$, (3). Also, there is a great consensus on the fact that children with worse health during the first 36 months of their lives are more likely to suffer from severe $\mathrm{MIH},(4)$.

Presently, we know more about MIH, but its etiology remains unknown. It is supposed to be of systemic origin and although a wide variety of etiological factors have been proposed as mediators in the onset of $\mathrm{MIH}$, a definitive agreement on its etiology has not yet been reached (5).

Among the possible etiological factors of $\mathrm{MIH}$, recent studies on the etiology of MIH point at the presence of immunological immaturity and, at present, it seems increa-
Uvod

Na sastanku Europske akademije za dječju stomatologiju (EAPD), održanom u Ateni 2003., prihvaćena je sintagma molarno-incizalna hipomineralizacija (MIH) koju su Weerheijm i suradnici (1) predložili 2001. godine. MIH se odnosi na poremećaje u razvoju zuba nepoznate etiologije koji utječe na trajne zube, a posebno pogađa prve trajne kutnjake i sjekutiće (2).

Istraživanja o MIH-u su česta i ta se tema trenutačno proučava u gotovo svim zemljama svijeta. Podatci o učestalosti, koji se danas razmatraju, kreću se između 2,4 i 40,2 \% (3). Uz to, stručnjaci se slažu u vezi s činjenicom da će djeca lošijega zdravlja tijekom prvih 36 mjeseci života češće patiti od teškoga MIH-a (4).

Danas znamo više o MIH-u, ali njegova točna etiologija još je nepoznata. Trebala bi biti sistemskog podrijetla, a iako je predložen širok spektar etioloških čimbenika kao posrednika u nastanku MIH-a, konačni dogovor još nije postignut (5).

Među mogućim etiološkim čimbenicima $\mathrm{MIH}$-a jedan od najrelevantnijih uzroka, na temelju nedavnih istraživanja o njegovoj etiologiji, jest imunosna nezrelost pa se čini sve jasnijim da uključuje disfunkciju imunosnog sustava tijekom djetetovih prvih godina (6). 
singly clear that the immune system dysfunction during the first years of the child's life is involved (6).

The pathogenesis of atopic dermatitis $(\mathrm{AD})$ - which is the most frequent chronic inflammatory disease of childhood - is not fully understood, but current evidence suggests that $\mathrm{AD}$ is characterized by a dysfunction of the skin barrier, $(7,8)$. Skin barrier defects allow environmental antigens to enter the body and interact with elements of the immune system, natural and acquired, causing a very intense Th2-type allergic response, (9).

$\mathrm{AD}$ is often the initial step of the "the atopic march". The atopic/allergic march is characterized by a typical sequence of immunological responses associated with the production of specific $\mathrm{IgE}$ against allergens. It begins with $\mathrm{AD}$ and progresses to IgE-mediated food allergy (FA), asthma, and allergic rhinitis (AR), (10).

Hernández et al (5) reported the significant relationship between $\mathrm{MIH}$ and the presence of $\mathrm{AD}$ and $\mathrm{FA}$, components of the so-called the atopic march, in a study on the etiological factors of MIH. Suspecting that the presence of MIH could be related to allergic march as a whole, the primary rationale for conducting the study was to analyse a sample of children diagnosed with MIH to determine whether or not there was any relationship with the components of allergic march.

\section{Material and Methods}

The study was based on the review of the medical records of a group of 102 children whose age was between eight and 12 years and 11 months. All the children -55 boys and 47 girls who had participated in the previous study on $\mathrm{MIH}^{5}$ without significant differences due to sex had the first four permanent molars and the eight permanent incisors erupted and had been previously diagnosed with $\mathrm{MIH}$. When MIH was diagnosed, all the children had been examined by a calibrated pediatric dentist. The dentist had been graded with an intra-examining Kappa factor of $97.6 \%$ (5).

The Institutional Review Board (Bioethical Committee, University of Barcelona, Spain) approved the study protocol (IRB00003099) for this study on the etiology of MIH. After informed consent was obtained, the medical records were checked for the presence or absence of $\mathrm{AD}$, asthmatic bronchitis, $\mathrm{FA}$, and allergic rhinitis, all components of the allergic march.

Data were analysed using the 24.0 SPSS statistical software $\left(\mathrm{IBM}^{\mathrm{TM}}\right)$ and a Pearson's $\chi^{2}$ test was used to evaluate associations in MIH etiology. A level of $\mathrm{p} \leq 0.05$ was considered statistically significant.

No children participants were excluded from the sample since all of them had been diagnosed with having MIH in their teeth in the previous study by the same author.

\section{Results}

A statistically significant association $\left(\chi^{2}, \mathrm{p} \leq 0.05\right)$ was found between atopic dermatitis, food allergies, allergic rhinitis, asthmatic bronchitis/asthma and the presence of $\mathrm{MIH}$ in children's mouths (Table 1).

When analyzing the pathologies by location, we realized that $\mathrm{AD}$ is more frequent in children who have \#31 $(\mathrm{OR}=2.23 ; 1.06-4.69$ CI $95 \%), \# 41 \quad(\mathrm{OR}=2.22 ; 1.04-4.68$
Patogeneza atopijskog dermatitisa $(\mathrm{AD})$ - a to je najčešća kronična upalna bolest u djetinjstvu (7) - nije potpuno razjašnjena, ali sadašnji dokazi upućuju na to da $\mathrm{AD}$ karakterizira disfunkcija korisne barijere kože. Oštećenja kožne barijere omogućuju okolišnim čimbenicima ulazak u tijelo i interakciju s prirodnim i stečenim elementima imunosnog sustava, što potiče vrlo intenzivan alergijski odgovor tipa 2 (9).

Zapravo, AD je često početak tzv. atopijskoga marša. Atopijski/alergijski marš obilježava tipičan niz imunosnih odgovora povezanih $s$ proizvodnjom alergospecifičnih $\operatorname{IgE}$ protutijela. Počinje s AD-om i napreduje do alergije na hranu posredovanu IgE-om (FA), astme i alergijskoga rinitisa (AR) (10).

Hernández i suradnici (5), u istraživanju o etiološkim čimbenicima $\mathrm{MIH}-\mathrm{a}$, istaknuli su značajan odnos između MIH-a i prisutnosti komponenta tzv. atopijskoga marša ADa i FA-a. Sumnja da bi MIH mogao biti povezan $s$ alergijskim maršem u cjelini, osnovni je razlog za analiziranje skupine djece s dijagnosticiranom MIH-om kako bi se doznalo postoji li ili ne veza s komponentama alergijskoga marša.

\section{Materijal i metode}

Istraživanje se temelji na pregledu medicinske dokumentacije 102 djeteta u dobi od 8 do 12 godina i 11 mjeseci. Sva djeca - 55 dječaka i 47 djevojčica - koja su sudjelovala u prethodnom istraživanju o MIH-u (5) bez znatnih razlika ovisno o spolu, imala su prva četiri trajna kutnjaka i osam trajnih sjekutića i već im je bio dijagnosticiran MIH. Kad je dijagnosticiran taj poremećaj, svu je djecu u sklopu ispitivanja pregledao kalibrirani pedijatrijski stomatolog s čimbenikom Kappa od $97,6 \%(5)$.

Mjerodavni odbor institucije (Bioetički odbor Sveučilišta u Barceloni, Španjolska) odobrio je protokol studije (IRB00003099) za ovo istraživanje o etiologiji MIH-a. Nakon dobivanja informiranog pristanka, u medicinskoj se evidenciji provjeravalo postoji li ili ne kod sudionika u studiji $\mathrm{AD}$, astmatični bronhitis, FA i alergijski rinitis te sve komponente alergijskoga marša.

Podatci su analizirani statističkim softverom 24,0 SPSS $\left(\mathrm{IBM}{ }^{\mathrm{TM}}\right)$, a Pearsonov test $\chi^{2}$ korišten je za procjenu povezanosti alergijskih stanja u MIH-ovoj etiologiji. Razina $\mathrm{p} \leq$ 0,05 smatrana je statistički značajnom.

$\mathrm{Ni}$ jedno dijete nije isključeno iz istraživanja jer je svim sudionicima isti stručnjak dijagnosticirao MIH na zubima.

\section{Rezultati}

Utvrđena je statistički značajna povezanost $(\chi 2, p \leq 0,05)$ između atopijskog dermatitisa, prehrambene alergije, alergijskog rinitisa i astmatičnog bronhitisa/astme i MIH-a u ustima djece (tablica 1.).

Analizirajući patologije prema mjestu na kojem su se pojavile, shvatili smo da je $\mathrm{AD}$ češći kod djece kojoj su zahvaćeni zubi \# $31(\mathrm{OR}=2,23 ; 1,06-4,69 \mathrm{CI} 95 \%)$, \# $41(\mathrm{OR}=$ 
Table 1. Association between atopic dermatitis, food allergies, allergic rhinitis and asthma with MIH.

Tablica 1. Odnos između atopijskog dermatitisa, prehrambenih alergija, alergijskog rinitisa i astme u odnosu prema dijagnosticiranom MIH-u

\begin{tabular}{|c|c|c|c|c|c|}
\hline & $\mathrm{OR} \cdot \mathrm{OV}$ & Lower • Donji & Upper • Gornji & $\chi^{2}$ & p \\
\hline Atopic dermatitis $\bullet$ Atopijski dermatitis & 2.5046 & 1.5468 & 4.0555 & 14.5698 & $\mathrm{p} \leq 0.01$ \\
\hline Food allergies $\bullet$ Prehrambene alergije & 2.1710 & 1.0316 & 4.5689 & 4.3493 & $\mathrm{p} \leq 0.05$ \\
\hline Allergic rhinitis $\bullet$ Alergijski rinitis & 0.1706 & 0.0229 & 1.2719 & 3.8126 & $\mathrm{p} \leq 0.05$ \\
\hline Asthma $\bullet$ Astma & 1.7070 & 1.0536 & 2.7655 & 4.7918 & $\mathrm{p} \leq 0.05$ \\
\hline
\end{tabular}

†OR (Odds Ratio), $\ddagger \chi^{2}$ (Pearson's Chi-square test) $\bullet$ †OV (omjer vjerojatnosti), $\ddagger \chi^{2}$ (Pearsonov Chi-kvadrat test)

CI 95\%), and \#42 (OR=1.65; 0.86-3.16 CI 95\%) affected. Regarding FA, we could see that they were more frequent in children with involvement of \#12 (OR=1.94; 1.48-2.54 CI 95\%), \#11 (OR=3.02; 1.30-7.03 CI 95\%), \#21 (OR=2.05; 1.53-2.76 CI 95\%), \#22 (OR=2.06; 1.09-3.90 CI 95\%), \#31 (OR=2.22; 1.10-4.50 CI 95\%), \#41 (OR=3.68; 1.19$11.37 \mathrm{CI} 95 \%)$ and \#42 (OR=2.94; 1.04-8.36 CI 95\%). Likewise, in our study, allergic rhinitis is related to the presence of MIH in \#11 (OR=2.63; 1.85-3.73 CI 95\%), \#21 $(\mathrm{OR}=3.47$; 1.34-8.99 CI 95\%), \#31 $(\mathrm{OR}=1.91 ; 1.07-3.39$ CI 95\%), \#41 (OR=1.14; 0.73-1.76 CI 95\%), and \#42 $(\mathrm{OR}=1.17$; 0.82-1.68 CI 95\%), while asthmatic processes manifested more frequently in children who had affected \#36 $(\mathrm{OR}=7.48 ; 2.53-22.24 \mathrm{CI} 95 \%), \# 41(\mathrm{OR}=3.07 ; 1.79-5.27$ CI 95\%), and \#42 (OR=2.14; 1.76-2.75 CI 95\%).

\section{Discussion}

Although it was recommended that children be observed at age eight when it comes to MIH studies, our sample ranged from age eigh to the day before their thirteenth birthday (11). In this study, this age range was used because it was considered that, once the tooth had erupted, the age at which it had erupted was not so important as whether it was affected by MIH.

Little is known about the etiological factors of $\mathrm{MIH}$ $(6,12-15)$. It has been suggested that there is a greater risk in children who during the first three years of their life have had, among others, adenoid infections, tonsillitis, respiratory diseases, diseases accompanied by high fevers and certain environmental pollutants $(6,16-19)$.

Several authors have reported the significant associations between postnatal diseases of atopic origin ( $\mathrm{AD}$, asthma, bronchitis or allergic rhinitis) and MIH. The research suggested that respiratory diseases and asthma may be causative factors of MIH (5,6,14,16,19-23).

However, other studies have found the associations not to be statistically significant $(12-14,19,24)$. Analyzing potentially associated factors, Souza et al (13) found no significant statistical association between allergies, and MIH. Sönmez et al (14) found no association between asthma, pneumonia, bronchitis and MIH. Dantas-Neta et al (24) indicate that asthma, bronchitis, sinusitis, and rhinitis, which were more prevalent in the MIH group, but not associated with $\mathrm{MIH}$, were among the variables analysed in the children's medical history during the postnatal period of life. Rhinitis, bronchitis and high fever were more prevalent but not significantly represented in the group of Brazilian children with $\mathrm{MIH}$ (19). In their recent paper Salem et al (25) have found "der-
$2,22 ; 1,04-4,68 \mathrm{CI} 95 \%)$ i \# $42(\mathrm{OV}=1,65 ; 0,86-3,16 \mathrm{CI}$ $95 \%$ ). Kad je riječ o FA-i, mogli smo vidjeti da je češća kod djece sa zahvaćenim zubima \# $12(\mathrm{OV}=1,94 ; 1,48-2,54 \mathrm{CI}$ $95 \%)$, \# $11(\mathrm{OV}=3,02 ; 1,30-7,03 \mathrm{CI} 95 \%)$, \# 21 (ILI = $2,05 ; 1,53-2,76$ CI $95 \%)$, \# $22(\mathrm{OV}=2,06 ; 1,09-3,90 \mathrm{CI}$ $95 \%)$, \# $31(\mathrm{OV}=2,22 ; 1,10-4,50 \mathrm{CI} 95 \%), \# 41(\mathrm{OV}=$ 3,68; 1,19 - 11,37 CI $95 \%)$ i \# $42(\mathrm{OV}=2,94 ; 1,04-8,36$ CI $95 \%)$. U našem je istraživanju alergijski rinitis također povezan s MIH-om na zubima \# $11(\mathrm{OV}=2,63 ; 1,85-3,73$ CI 95\%), \# 21 (OV = 3,47; 1,34-8,99 CI 95\%), \# 31 (ILI $=1,91 ; 1,07-3,39$ CI $95 \%)$, \# $41(\mathrm{OV}=1,14 ; 0,73-1,76$ CI $95 \%)$ i \# $42(\mathrm{OV}=1,17 ; 0,82-1,68 \mathrm{CI} 95 \%)$, a astmatični procesi češće su se manifestirali i utjecali na zube \# 36 $(\mathrm{OV}=7,48 ; 2,53-22,24 \mathrm{CI} 95 \%)$, \# $41(\mathrm{OV}=3,07 ; 1,79$ $-5,27$ CI $95 \%)$ i \# $42(\mathrm{OV}=2,14 ; 1,76-2,75$ CI $95 \%)$.

\section{Rasprava}

Iako se preporučuje da se djeca promatraju u dobi od osam godina, kada je riječ o istraživanju MIH-a (11), naš se uzorak djece kretao od 8 godina do njihova 13. rođendana. $\mathrm{U}$ ovom istraživanju primijenjen je taj dobni raspon jer se smatralo da, kada je zub niknuo, nije toliko važno u kojoj se dobi to dogodilo, nego je li utjecao na MIH ili nije.

Malo se zna o etiološkim čimbenicima MIH-a $(6,12-$ 15), no pretpostavlja se da postoji veći rizik kod djece koja su tijekom prve tri godine poslije rođenja imala adenoidne infekcije (16), tonzilitis (17), respiratorne bolesti, bolesti s jakom groznicom i one uzrokovane određenim onečišćivačima okolišsa $(6,18,19)$.

Nekoliko autora je istaknulo značajnu povezanosti između postnatalnih bolesti atopijskog podrijetla (AD, astma, bronhitis ili alergijski rinitis) i MIH-a. Respiratorne bolesti i astma predloženi su kao uzročni čimbenici MIH -a $(5,6,14$, $16,19-23)$.

No u drugim se studijama ističe da te veze nisu statistički značajne $(12-14,19,24)$. Analizirajući potencijalno povezane čimbenike, Souza i suradnici (13) nisu ustanovili značajnu statističku povezanost između alergija i MIH-a. Sönmez i njegovi kolege (14) nisu pronašli povezanost između astme, upale pluća, bronhitisa i MIH-a. Dantas-Neta i suradnici (24) pokazali su da su među varijablama analiziranima u dječjoj medicinskoj povijesti tijekom postnatalnog razdoblja bili astma, bronhitis, sinusitis i rinitis, koji su bili češći u skupini s MIH-om, ali s njime nisu bili značajno povezani. Rinitis, bronhitis i jaka groznica bili su češći, ali ne i značajno, u skupini brazilske djece s MIH-om (19). U nedavnom radu su Salem i suradnici (25) pronašli da je dermatitis alergijskog podrijetla statistički značajan prediktor za 
matitis of allergic origin" to be a statistically significant predictor for MIH, although not many details about how the study was performed are given.

It has been suggested that hypoxia may play a major role as a causal factor in the development of enamel deformations upon acting on the ameloblasts during the active phase (14). Experimental studies reveal that the conditions affecting the $\mathrm{pH}$ of the enamel matrix in various respiratory diseases inhibit the action of the proteolytic enzymes and the precursors of enamel affecting ameloblastic activity and altering development of hydroxyapatite crystals resulting in enamel's hypomineralisation (26).

Atopic dermatitis is a childhood disease with immunological and skin barrier malfunction showing a high degree of comorbidity. The term atopy represents IgE-mediated hypersensitivity reactions (7).

Our environment and lifestyle are changing very rapidly and the appearance of new pollutants that may affect the period of amelogenesis could be an etiological factor to consider in future studies (27).

Endocrine Disrupting Chemicals (EDCs) are exogenous substances that alter functions of the endocrine system and consequently cause adverse health effects in an intact organism (28).

Many of the proposed causal factors for MIH, including EDCs, involve the large family of the steroid receptors. Most of them are expressed in ameloblasts and their levels of expression are dependent on their stage of differentiation (29). Steroid receptors thus appear as the common elements able to modulate the expression of enamel key genes controlling enamel synthesis or leading to enamel hypomineralisation in case of disruption (27).

Exposure to EDCs alters innate and adaptive immune mechanisms interfering with cellular and humoral activities that affect cell maturation and lifespan (30).

Atopic comorbidities (AD, AR, and asthma) are common and often appear together (31). They usually begin early in life with their co-occurrence greater than expected by chance alone, regardless of $\operatorname{IgE}$ sensitization (32). A dysfunctional skin barrier is a gateway for the entry of environmental and bacterial antigens facilitating the allergic sensitization and promoting a systemic lymphocytic immune response of type Th2, (33).

Currently, the prevailing theory defines $\mathrm{AD}$ as a starting point of the allergic march and signals the skin as being mainly responsible for early allergic sensitization that occurs in patients with $\mathrm{AD}$ suggesting a cutaneous and systemic immune activation (34).

Our study found a significant relationship $(\mathrm{p} \leq 0,05)$ between having MIH and having or having had atopic dermatitis, food allergies, allergic rhinitis, and asthma.

Today, there is a research path that follows the idea that genetic variations and agents that act negatively on the skin barrier and its development may be at the root of amelogenesis alterations since the enamel formation process is genetically controlled (21).

Jeremias et al (35) were the first to evaluate the possibility that the genetic mutations somehow interact with the envi-
$\mathrm{MIH}$, iako nema mnogo detalja o tome kako je provedeno istraživanje.

Pretpostavlja se da hipoksija može biti važan uzročni čimbenik u razvoju deformacija cakline nakon djelovanja na ameloblaste tijekom njihove aktivne faze (14). U eksperimentalnim istraživanjima otkriveno je da uvjeti koji utječu na $\mathrm{pH}$ caklinske matrice, kod različitih respiratornih bolesti, inhibiraju djelovanje proteolitičkih enzima i prekursora cakline koji pak utječu na aktivnost ameloblasta i tako mijenjaju razvoj kristala hidroksiapatita, što rezultira hipomineralizacijom cakline (26).

Atopijski dermatitis dječja je bolest s poremećajem imunosne i barijere kože koja pokazuje visok stupanj komorbiditeta. Atopija je zapravo reakcija preosjetljivosti uz posredovanje IgE protutijela (7).

Naše se okružje i način života vrlo brzo mijenjaju, pa bi pojava novih onečišćivača koji mogu utjecati na razdoblje amelogeneze mogla biti etiološki čimbenik koji treba uzeti u obzir u budućim studijama (27).

Kemikalije koje potiču poremećaje endokrinog sustava (EDC) vanjske su tvari koje mijenjaju funkciju endokrinog sustava i posljedično uzrokuju štetne zdravstvene učinke u netaknutom organizmu (28).

Mnogi od predloženih uzročnih čimbenika za MIH, uključujući i EDC, obuhvaćaju veliku obitelj steroidnih receptora. Većina njih je na ameloblastima i njihova razina ekspresije ovisi o stupnju diferencijacije (29). Tako se steroidni receptori pojavljuju kao zajednički elementi koji mogu modulirati ekspresiju ključnih gena cakline koji kontroliraju sintezu cakline ili potiču njezinu hipomineralizaciju u slučaju poremećaja (27).

Izloženost EDC-ima mijenja prirođene i stečene imunosne mehanizme koji interferiraju sa staničnim i humoralnim aktivnostima koji, pak, utječu na starenje i životni vijek stanica (30).

Atopijski komorbiditeti (AD, AR i astma) uobičajeni su i često se pojavljuju zajedno (31). Obično počinju u djetinjstvu istodobno s pojavom tih poremećaja većom nego što je očekivano, bez obzira na IgE senzibilizaciju (32). Disfunkcionalna kožna barijera mjesto je ulaska okolišnih i bakterijskih antigena koji olakšavaju alergijsku senzibilizaciju i potiču sistemski imunosni odgovor limfocita tipa 2 (33).

Trenutačno prihvaćena teorija definira $\mathrm{AD}$ kao polazište alergijskoga marša i upućuje na kožu kao na glavnu odgovornu značajku za ranu alergijsku senzibilizaciju koja se pojavljuje kod pacijenata s $\mathrm{AD}$-om, a pokreće kožnu i sistemsku imunosnu aktivaciju (34).

$\mathrm{U}$ našem istraživanju otkrili smo značajnu povezanost ( $\mathrm{p}$ $\leq 0,05)$ između MIH-a i atopijskog dermatitisa, prehrambenih alergena, alergijskog rinitisa i astme.

Danas postoji istraživački put koji slijedi ideju da genske varijacije i agensi koji djeluju negativno na kožnu barijeru i na njezin razvoj, mogu biti uzrokom promjena u amelogenezi jer je proces stvaranja cakline genski kontroliran (21). Jeremias i suradnici (35) prvi su procijenili da genske mutacije možda djeluju uzajamno s čimbenicima okoliša i da su povezane s postupkom amelogeneze i MIH-om.

Razlike između istraživanja o mogućim etiološkim čim- 
ronmental factors and are associated with the amelogenesis process and the presence of MIH.

Discrepancies between the studies regarding the possible etiological factors of MIH highlight the importance of conducting more research on this pathology.

\section{Conclusion}

The statistically significant and widely demonstrated association between MIH and the presence of atopic diseases in the first years of a child's life underlines the convenience of approaching this problem from a multifocal perspective.

Pediatric dentists must take into account in their protocols that children with $\mathrm{AD}$ and atopic comorbidities are more likely to suffer MIH and that they should advise parents of children with the atopic march about the need for increased oral health care for their children.

\section{Conflict of interest}

None declared

\section{Author contributions}

$\mathrm{MH}$ conceived the idea, collected the data, led the writing, and gave the final approval of the version to be published; JM analysed the data, critically reviewed the manuscript, and gave the final approval of the version to be published. benicima MIH-a pokazuju koliko su važna dodatna buduća istraživanja te patologije.

\section{Zaključci}

Statistički značajna povezanost između MIH-a i atopijskih bolesti u prvim godinama djetetova života pokazuje nam pogodnost pristupa tom problemu iz multifokalne perspektive. Pedijatrijski stomatolozi moraju uzeti u obzir u svojim protokolima da će djeca s $\mathrm{AD}$-om i atopijskim komorbiditetima češće patiti od MIH-a i da bi trebali objasniti njihovim roditeljima što je to atopijski marš i zašto je njihovoj djeci potrebna povećana oralna zdravstvena zaštita.

\section{Sukob interesa}

Autori nisu bili u sukobu interesa.

\section{Osobni doprinosi autora}

M. H. je dao ideju, skupio podatke, zapisivao ih i dao dopuštenje za konačnu inačicu i objavu teksta. J. M. je analizirao podatke, kritički pregledao i analizirao članak te dao konačno dopuštenje za slanje članka u tisak.
Sažetak

Svrha: Molarno-incizalana hipomineralizacija (MIH) poremećaj je u razvoju zuba koji zahvaća prve trajne kutnjake i sjekutiće s prevalencijom od 2,5 do $40 \%$. Cilj ovog istraživanja bio je ispitati utjecaj atopijskih bolesti na razvoj molarno-incizalne hipomineralizacije. Materijal i Metode: Istraživanje se temeljilo na pregledu medicinske dokumentacije 102 djeteta u dobi između 8 i 12 godina i 11 mjeseci s već dijagnosticiranim MIH-om. Rezultati: Pronađena je povezanost $\left(X^{2}, p \leq 0,05\right)$ između $M I H$ a u ustima djece i atopijskog dermatitisa (OV $=2,504 ; 1,54-4,05 \mathrm{Cl} 95 \%)$, alergije na hranu (OV= $2,171 ; 1,03-4,56 \mathrm{Cl} 95 \%)$, alergijskog rinitisa ( $\mathrm{OV}=0,17 ; 0,02-1,27 \mathrm{Cl} 95 \%$ ) i astmatičnog bronhitisa/astme (OV = 1,770; 1,05-2,76 Cl $95 \%)$. Analizirajući patologije prema mjestu pogođenosti MIH-a, otkrili smo da su atopijski dermatitis, alergija na hranu, alergijski rinitis i astma češći kod djece koja su imala ( $<<0,05)$ zahvaćene zube \# 12, \# 11, \# 21, \# 22, \# 36, \# 31, \# 41 i \# 42. Zaključci: Povezanost MIH-a i atopijskih bolesti u prvih 36 mjeseci djetetova života pokazuje koliko je tom problemu potreban multidisciplinarni pristup.
Zaprimljen: 1 . siječnja 2020

Prihvaćen: 15. travnja 2020

Adresa za dopisivanje

Prof. M. Hernández

University of Barcelona

Dental School

Department of Pediatric Dentistry

Feixa Llarga s/n, 08907

L'Hospitalet de Llobregat, Barcelona,

Spain.

tel: +34934024269

faks: +34934035558

m_hernandez_j@ub.edu

Ključne riječi

hipoplazija zubne cakline; atopijski dermatitis; preosjetljivost na hranu; alergijski rinitis; demineralizacija zuba; dijete

\section{References}

1. Weerheijm KL, Jalevik B, Alaluusua S. Molar-incisor hypomineralisation. Caries Res. 2001 Sep-Oct;35(5):390-1.

2. Weerheijm KL, Duggal M, Mejàre I, Papagiannoulis L, Koch G, Martens $L$, et al. Judgement criteria for molar incisor hypomineralisation (MIH) in epidemiologic studies: a summary of the European meeting on MIH held in Athens, 2003. Eur J Paediatr Dent. 2003 Sep;4(3):110-3.

3. Hernández M, Boj JR, Espasa E. Do we really know the prevalence of MIH? J Clin Pediatr Dent. 2016;40(4):259-63.

4. Ghanim AM, Manton DJ, Morgan MV, Mariño RJ, Bailey DL. Trends of oral health care and dental treatment needs in relation to molar incisor hypomineralisation defects: a study amongst a group of Iraqui children. Eur Arch Paediatr Dent. 2012 Aug;13(4):171-8.
5. Hernandez M, Boj JR, Espasa E, Planells P, Peretz B. Molar-Incisor Hypomineralization: Positive Correlation with Atopic Dermatitis and Food Allergies. J Clin Pediatr Dent. 2018;42(5):344-348.

6. Silva MJ, Scurrah KJ, Craig JM, Manton DJ, Kilpatrick N. Etiology of molar incisor hypomineralization. A systematic review. Community Dent Oral Epidemiol. 2016 Aug;44(4):342-53.

7. Kapur S, Watson W, Carr S. Allergy Asthma Clin Immunol. 2018 Sep 12;14(Suppl 2):52.

8. Egawa G, Kabashima K. Multifactorial skin barrier deficiency and atopic dermatitis: essential topics to prevent the atopic march. J Allergy Clin Immunol. 2016 Aug;138(2):350-358.e1.

9. Nakajima S, Kitoh A, Egawa G, Natsuaki Y, Nakamizo S, Moniaga CS, et al. IL-17A as an inducer for Th2 immune respons- 
es in murine atopic dermatitis models. J Invest Dermatol. 2014 Aug;134(8):2122-2130.

10. Hill DA, Spergel JM. The atopic march: critical evidence and clinical relevance. Ann Allergy Asthma Immunol 2018; 120:131-7.

11. Hernández M, Boj JR, Espasa E, Peretz B. First Permanent Molars and Permanent Incisors Teeth by Tooth Prevalence of Molar-Incisor-Hypomineralisation in a Group of Spanish Schoolchildren. Acta Stomatol Croat. 2018 Mar;52(1):4-11.

12. Alaluusua $\mathrm{S}$. Aetiology of molar incisor hypomineralisation: a systematic review. Eur Arch Paediatr Dent. 2010 Apr;11(2):53-8.

13. Souza JF, Costa-Silva CM, Jeremias F, Santos-Pinto L, Zuanon AC, Cordeiro RC. Molar incisor hypomineralisation: possible aetiological factors in children from urban and rural areas. Eur Arch Paediatr Dent. 2012 Aug;13(4):164-70.

14. Sönmez H, Yildirim G, Bezgin T. Putative factors associated with molar incisor hypomineralisation: an epidemiological study. Eur Arch Paediatr Dent. 2013 Dec;14(6):375-80.

15. Fagrell T, Ludvigsson J, Ullbro C, Lundin SA, Koch G. Aetiology of severe demarcated enamel opacities-an evaluation based on prospective medical and social data from 17,000 children. Swed Dent J. 2011;35(2):57-67.

16. Allazzam SM, Alaki SM, El Meligy OA. Molar incisor hypomineralization, prevalence, and etiology. Int J Dent. 2014;2014:234508.

17. Whatling R, Fearne JM. Molar incisor hypomineralization: a study of aetiological factors in a group of UK children. Int J Paediatr Dent. 2008 May;18(3):155-62.

18. Seow WK. Developmental defects of enamel and dentine: challenges for basic science research and clinical management. Aust Dent J. 2014 Jun;59 Suppl 1:143-54.

19. Souza JF, Jeremias F, Costa-Silva CM, Santos-Pinto L, Zuanon AC, Cordeiro RC. Aetiology of molar-incisor hypomineralisation (MIH) in Brazilian children. Eur Arch Paediatr Dent. 2013; 14:233-8.

20. Kılınc G, Cetin M, Kose B, Ellidokuz H. Prevalence, aetiology, and treatment of molar incisor hypomineralization in children living in Izmir City (Turkey). Int J Paediatr Dent. 2019; 29:775-82.

21. Tourino LF, Correa-Faria P, Ferreira RC, Bendo CB, Zarzar PM, Vale MP. Association between molar incisor hypomineralization in schoolchildren and both prenatal and postnatal factors: a population-based study. PLoS One. 2016 Jun 9;11(6):e0156332.

22. Fatturi AL, Wambier LM, Chibinski AC, Assunçao LR, Brancher JA, Reis A, et al. A systematic review and meta-analysis of systemic exposure associated with molar incisor hypomineralization. Community Dent Oral Epidemiol. 2019 Oct;47(5):407-415.
23. Pitiphat W, Luangchaichaweng S, Pungchanchaikul P, Ang waravong $\mathrm{O}$, Chansamak N. Factors associated with molar in cisor hypomineralization in Thai children. Eur J Oral Sci. 2014 Aug;122(4):265-70.

24. Dantas-Neta NB, Soares M, Branco C, Baccin C, Matos de Andrade E, Moura M, et al. Factors associated with molar-incisor hypomineralisation in schoolchildren aged $8-10$ years: a case-control study. Int J Paedr Dent. 2018; 28:570-7.

25. Salem K, Aziz D, Asadi M. Prevalence and predictors of molar incisor hypomineralization $(\mathrm{MIH})$ among rural children in northern Iran. Letter to the editor. Iran J Public Health 2016; 45:1528-30.

26. Garg N, Jain AK, Saha S, Singh J. Essentiality of early diagnosis of molar incisor hypomineralization in children and review of its clinical presentation, etiology and management. Int J Clin Pediatr Dent. 2012 Sep;5(3):190-6.

27. Babajko S, Jedeon K, Houari S, Loiodice S, Berdal A. Disruption of Steroid Axis, a New Paradigm for Molar Incisor Hypomineralization (MIH). Front Physiol. 2017 May 26;8:343.

28. WHO Regional Office for Europe, Copenhagen. The European health report 2002. WHO Reg Publ Eur Ser. 2002;(97):2-5.

29. Houari S, Loiodice S, Jedeon K, Berdal A, Babajko S. Expression of steroid receptors in ameloblasts during amelogenesis in rat incisors. Front Physiol. 2016 Nov 2;7:503.

30. Nowak K, Jabłońska E, Ratajczak-Wrona W. Immunomodulatory effects of synthetic endocrine disrupting chemicals on the development and functions of human immune cells. Environment International 2019; 125:350-64.

31. Weidinger S, Beck LA, Bieber T, Kabashima K, Irvine AD. Nat Rev Dis Primers. 2018 Jun 21;4(1):2.

32. Pinart M, Benet M, Annesi-Maesano I, von Berg A, Berdel D, Carlsen KC, et al. Comorbidity of eczema, rhinitis, and asthma in IgE-sensitised and non-IgE sensitized children in MeDALL: a population-based cohort study. Lancet Respir Med. 2014 Feb;2(2):131-40

33. Werfel T, Allam JP, Biedermann T, Eyerich K, Gilles S, GuttmanYassky E, et al. Cellular and molecular immunologic mechanisms in patients with atopic dermatitis. J Allergy Clin Immunol. 2016 Aug;138(2):336-49.

34. Brunner PM, Silverberg JI, Guttman-Yassky E, Paller AS, Kabashima K, Amagai M, et al. Increasing Comorbidities Suggest that Atopic Dermatitis Is a Systemic Disorder. J Invest Dermatol. 2017 Jan;137(1):18-25.

35. Jeremias F, Pierri RA, Souza JF, Fragelli CM, Restrepo M, Finoti LS, et al. Family-Based Genetic Association for Molar-Incisor Hypomineralization. Caries Res. 2016;50(3):310-8. 